\title{
Approaches of Landscape Architects to Applications for the Use of Open and Green Spaces in Conditions of Covid-19 Pandemic
}

\author{
Covid-19 Salgını Koşullarında Açık ve Yeşil Alanların Kullanımına Yönelik \\ Uygulamalara Peyzaj Mimarlarının Yaklaşımları
}

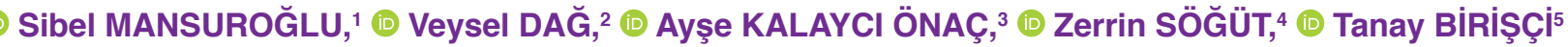

\section{ABSTRACT}

Open and green areas, including areas such as parks, urban forests, daily recreation areas, residential gardens, can take on the task of changing the spatial system. Especially during epidemic/pandemic periods, people's longing for nature gradually increases and this situation can lead to the emergence of various social problems. This study tried to put forward the views of Landscape Architects, who undertake important duties in the planning, design, implementation and sustainability of open and green spaces offered to the public, on the use of open and green spaces during the pandemic process and applications made in this regard through a survey. As a result of the survey conducted with 400 Landscape Architects, it was emphasized that the use of open and green areas is necessary in order to support public health during the pandemic period, but the necessity of various measures such as disinfection, physical distance, and re-handling of the use of urban furniture has been acknowledged. Understanding the socio-spatial consequences of the measures taken to prevent the spread of the epidemic and determining new concepts related to lifestyles that combine working and life patterns and arising from new spatial environments are among the benefits to be gained from the study. Based on the findings obtained through this study, it can be stated that Landscape Architects need to gain experience in nature, natural factors and health relations in order to be able to design urban green spaces in harmony with nature and with consideration to public health.

Keywords: Covid-19; landscape architect; open and green area; pandemic.

Park, kent ormanları, günlük rekreasyon alanları, konut bahçeleri gibi alanları içeren açık ve yeşil alanlar mekânsal sistemi değiştirme görevini üstlenebilirler. Özellikle salgın hastalık dönemlerinde halkın doğaya özlemi giderek artmakta ve bu durum çeşitli toplumsal sorunların ortaya çıkmasına kadar varabilmektedir. Bu çalışmada, halkın kullanımına sunulan açık ve yeşil alanların planlanma, tasarım, uygulama ve sürdürülebilirliğinde önemli görevler yüklenen peyzaj mimarlarının salgın hastalıklar sürecinde açık ve yeşil alanların kullanımı ve bu konuda yapılan uygulamalara yönelik görüşleri Covid-19 salgını örneğinde anket aracılığı ile ortaya konulmaya çalışılmıştır. Dört yüz peyzaj mimarı ile yapılan anket çalışması sonucu salgın hastalıklarla mücadelede toplum sağlığını desteklemek amacıyla açık ve yeşil alanların kullanımının gerekli olduğu ancak, kullanımın dezenfeksiyon, fiziksel mesafe, kent mobilyalarının kullanımının yeniden ele alınması gibi çeşitli önlemler gerektirdiği üzerinde durulmuştur. Salgının yayılmasını önlemede alınan önlemlerin sosyomekânsal sonuçlarının anlaşılması ile çalışma ve yaşam kalıpIarını birleştiren, ortaya çıkan yeni yaşam tarzları ile ilgili kavramların belirlenmesi çalışmadan elde edilecek faydalar arasındadır. Elde edilen bulgulara dayanılarak peyzaj mimarlarının kentsel yeşil alanları doğa ile uyumlu olarak tasarlayabilmeleri ve halk sağlığını dikkate alabilmeleri için doğa, doğal etkenler ve sağlık ilişkileri konusunda tecrübe kazanmaları gerektiği ifade edilebilir.

Anahtar sözcükler: Covid-19; peyzaj mimarı; açık ve yeşil alan; salgın hastalık.

'Department of Landscape Architecture, Akdeniz University Faculty of Architecture, Antalya, Turkey ${ }^{2}$ Department of Landscape Architecture, Pamukkale University Faculty of Architecture and Design, Denizli, Turkey ${ }^{3}$ Department of City and Regional Planning, İzmir Katip Çelebi University Faculty of Engineering and Architecture, İzmir, Turkey ${ }^{4}$ Department of Landscape Architecture, Çukurova University Faculty of Architecture, Adana, Turkey ${ }^{5}$ Department of Landscape Architecture, Ege University Faculty of Agriculture, İmir, Turkey

Article arrival date: March 30, 2021 - Accepted for publication: June 16, 2021

Correspondence: Sibel MANSUROĞLU. e-mail: smansur@akdeniz.edu.tr

○ 2021 Yıldız Teknik Üniversitesi Mimarlık Fakültesi - @ 2021 Yıldız Technical University, Faculty of Architecture 


\section{Introduction}

Today, more than $50 \%$ of the global population lives in urban areas. The urban area is expected to nearly triple from 2000 to 2030 (SCBD, 2013; Anguluri and Narayanan, 2017) worldwide. The rate of urban population has changed 68,8\% from 1927 to 2020 in Turkey (TUIK, 2021). Parallel to the increase in the population density in cities, the need for open and green areas, which have effective benefits on both urban ecology and psychological and physical human health, is increasing.

Cranz (2000) emphasizes the necessity of changing the existing design understanding and developing an approach that brings solutions to the ecological problems of the city and emphasizes human-nature relations in today's urban green areas, which are organized by prioritizing human use. In this context, she states that the multifaceted perspective of ecological design is a must in terms of integrating urban green areas with design and management practices, protecting natural resources and transferring them to future generations.

According to Akpınar (2019), physical inactivity has become an important issue that is defined by the World Health Organization as the fourth leading risk factor causing natural deaths globally (WHO, 2021). Open and green spaces shaped by the needs of city dwellers are seen today as an integral part of land use planning decisions in many countries (Maruani and Amit-Cohen, 2007). Open and green areas, including areas such as parks, urban forests, daily recreation areas, residential gardens, can take on the task of changing the spatial system. In addition, they have economic (energy saving, tourism and business opportunity development, increasing property value, providing raw materials to the forest industry, etc.), ecologic (being a direct source of oxygen, absorption of harmful gases and particles, contributing to climatic comfort in the city, erosion prevention and ensuring the water balance, improving the quality of groundwater, increasing biodiversity, screening harmful wind and noise, etc.), social (providing an environment for educational and cultural activities, playing a role in reducing the crime rate, allowing recreational activities, contributing to social development and playing a role in conversation of public health, providing social and psychological services for the welfare of city residents, etc.), and physical (circulationaccess function, space protection function, aesthetics, functioning as a buffer, protection of historical and cultural heritage, architectural effect, etc.) functions (Chiesura, 2004; EEA, 2012; Jones et al., 2012; Önder and Polat 2012; Kabisch et al., 2015; Ferrini and Gori, 2020).

The disease caused by the Covid-19 virus, which emerged in Wuhan, China on December 1, 2019, was declared a pandemic by the World Health Organization on March 11, 2020. According to the WHO report, public health and social measures must be implemented with the participation of all members of the society in order to slow down or stop the spread of Covid-19, and a global struggle must be carried out (WHO, 2021). As of March 29, 2021; 219 countries and regions in the world were affected by the pandemic, nearly 128 million people worldwide were infected, approximately 103 million of them recovered, and approximately 2 million 800 thousand people died (Worldometers, 2021). In Turkey, 3240577 people were infected with the disease on the same date, and 31 230 people died (T.R. Ministry of Health, 2021). But the numbers are changing rapidly.

The first case detected in Turkey in the Covid-19 outbreak was announced on March 11, 2020, and the Ministry of Health has announced the spread of the virus as of April 1, 2020. Depending on the increase in the number of daily cases, over time, regional (urban travel restrictions, lockdown), national (intercity travel restrictions, interruption of education, banning gatherings, mass demonstrations, communal prayers, etc., flexible working arrangements in public institutions, lockdown on a national scale) and international (international arrival-departure travel restrictions) measures have been taken. The most striking of these is the lockdown towards reducing the spread of the pandemic by restricting the free movement of the people and the closure of open and green areas. The most extensive of the restrictions, which started gradually in provinces where age groups, population density and chronic diseases are intense, first started with the banning of people from going out on the streets on 11-12 April 2020, and then spread throughout the country. In the following process, the lockdowns imposed on National and religious holidays continued until the second week of May 2020. Due to the fact that the number of cases increasing throughout the country could not be prevented in the controlled social life practice that started in May, the lockdown has started to be applied again, starting from the first week of December 2020, from 21.00 on every Friday until 05.00 on the following Monday. As of this date, the lockdowns of certain age groups have also been rearranged and the regulations introduced with these restrictions are still ongoing.

Isolation plays an important role in reducing the rate of contamination and significantly changes the daily life of the population (Caria et al., 2020). It has been pointed out that this situation may trigger posttraumatic stress disorder, anxiety and anger attacks (Brooks et al., 2020). Depending on the socialization needs of individuals and their psychological conditions that develop due to prohibitions, the demand for open and green spaces and other public open spaces has increased. As a result of the 
accumulation in these areas, maintaining the physical distance between individuals has become difficult. This situation brought the issue of the applicability of carrying capacity studies, which was developed for the sustainable management of pasture areas and then protected areas, in urban open and green areas because the appropriate physical distance between individuals will only be possible by calculating how many people will be using it at the same time, depending on the size of the area.

In our country, the use of open and green areas was restricted during the pandemic period, while these areas were closed for use during periods of lockdowns, and were opened to the use of citizens aged 65 and over in periods of partial flexibility.

In this process, it has been noticed that there was a need for determining the carrying capacity at the entrance to open and green areas, especially in metropolitan cities, and a certain number of people were allowed into these areas in a controlled manner. In the forthcoming periods, along with the transition into controlled social life, many local governments, especially in metropolitan cities, tried to limit the area used by a family and/or group of friends of 3-4 people in order to maintain social distance in open and green areas by drawing circles in certain sizes (3-4 m in diameter) and distances (2-3 m intervals).

When the data of Our World in Data (2021) is examined (Figure 1), a mobility change is observed in our country compared to the period before the Covid-19 pandemic. Accordingly, in the restriction periods, a decrease of up to $56,29 \%$ ( 25 April 2020) was experienced in the use of park areas, especially in open and green areas. It is seen that the park areas are the most used places amid controlled social life and that these areas hosted $79,29 \%$ of visitors on 5 August 2020. According to Berman (2020), insufficient green areas for the population living in a city are a public health problem. Since the time spent outdoors is important in combating the Covid-19 pandemic, it is necessary to invest in green areas in cities.

It is hereby recognized that wide open and green areas are used for the establishment of field hospitals, temporary morgues, and burial areas during the epidemic process in the US, China, and some European countries. Conversion of city parks into tent cities and construction of container cities in some open areas in Turkey during the Covid-19 pandemic period in 2020 after the earthquakes in Elazığ and İmir reveal that such areas could undertake different functions. Given the properties of urban open and green areas, it is critical to address them within the context of urban planning. According to Venter et al. (2020), experiences in crisis periods revealed that the open and green spaces guiding the ecological values of the cities and its importance for sustainable cities, and the access of the public to these areas under equal conditions will be among the important issues we may encounter in the future.

Frederick Law Olmsted, considered to be the founder of the profession of landscape architecture, regarded green areas like the lungs of cities, and always defended the rehabilitative power of these areas where polluted air is replaced with clean air. Planning works for Central Park in New York started right after the second cholera epidemic in New York. Upon the success of this project and after losing his first child, Olmsted designed more than 100 public parks and recreation areas in the USA based on the urban open and green space system (Anonymous, 2020). The necessity of creating areas for walking, cycling, exercising, and recreation and carrying out necessary works in neighbourhoods that do not have access to parks within walking distance ( $<10-15$ minutes) were highlighted

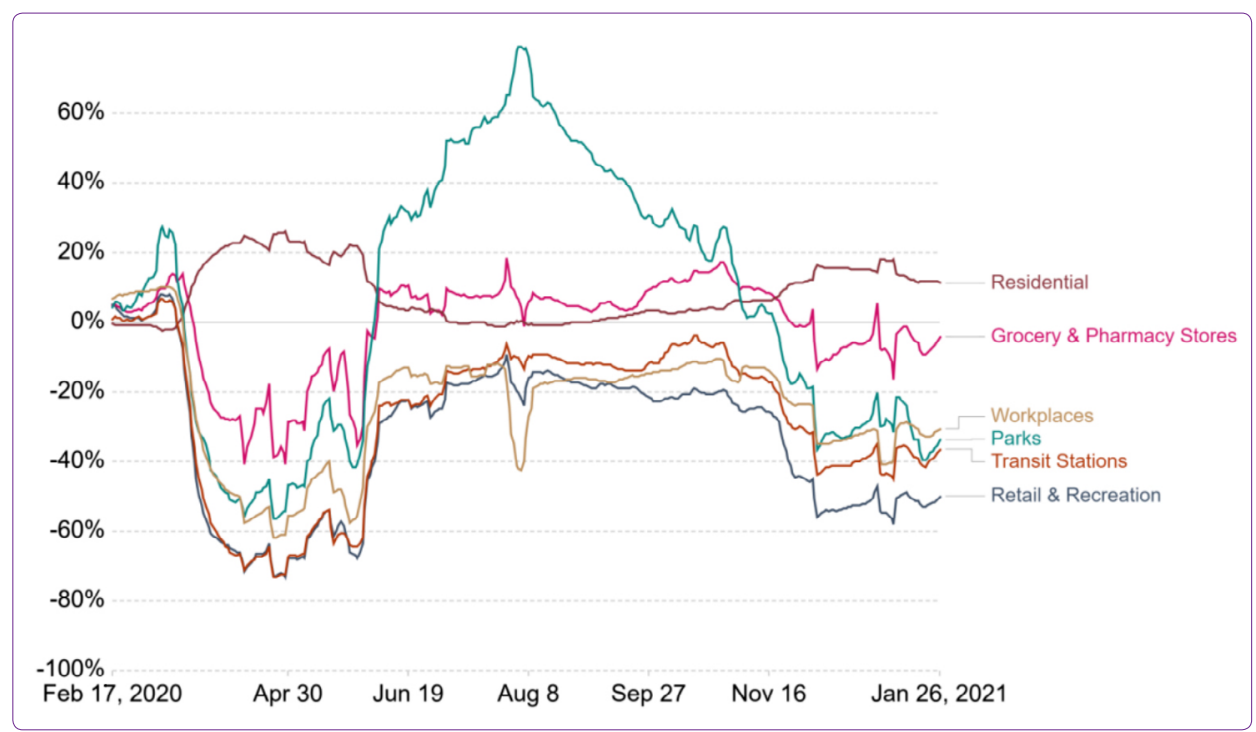

Figure 1. Community mobility in Turkey during the Covid-19 pandemic (Our World in Data, 2021). 
in a survey conducted with over 2000 people from 40 US states, 68 countries, and each continent (except Antarctica) on the use of public areas during the Covid-19 pandemic (O'Connor, 2020).

The new living conditions that emerged due to the Covid-19 pandemic affected social life as much as the economic system all over the world and the results of spatial organization disconnected from nature were clearly experienced. In this context, efforts should be made to reconsider urban design on a larger scale, taking into account infrastructure and physical distance on the basis of the pandemic, which directly and negatively affects people living in cities (Davies, 2020). In addition to its numerous ecological services, the only alternative that citizens can use to integrate with nature in the daily life pattern of urban life is open and green spaces. This study aims to determine the points of view of Landscape Architects, who are the most effective and competent professional group in the planning, design, implementation, and sustainability of open and green spaces in cities, on the effects of these areas on cities and urban environments during and after the pandemic as well as the development of new approaches for urban open and green areas after the pandemic within the scope of the Covid-19 experience.

\section{Materials and Methods}

\section{Materials}

The study is based on the evaluation of Landscape Architects' views on the use of open and green spaces in pandemic conditions. The main materials of the study are given below.

- Individuals who have received the title of Landscape Architect,

- Interview guides used to determine the views of Landscape Architects on the use of open and green areas in pandemic conditions,

- Studies on the subject,

- SPSS20, Microsoft Word, and Excel software used in the computer environment in the study for the evaluation of surveys (interview guides).

\section{Methods}

The research consists of the stages of determining the scope and method, collecting the information about the study subject, determining the sampling size, selecting the inquiry method, preparing the survey, pre-testing the survey and correcting the errors, applying the survey, and evaluating the results of the survey.

\section{Determining Sampling Size}

The sampling size of the survey study was calculated by using the formula suggested by Baş (2001), taking into account the size of the relevant population. The target group of the study, Landscape Architects living in Turkey, represents the relevant population. As of June 23, 2020, the number of members registered to the Union of Chambers of Turkish Engineers and Architects (TMMOB) Chamber of Landscape Architects was accepted as the population of the study (TMMOB Chamber of Landscape Architects, 2020). The sample was calculated according to a $5 \%$ margin of error ( $95 \%$ confidence interval). Accordingly, conducting a survey with 366 people represents the relevant population. However, considering the possibility of incomplete, incorrect, and invalid surveys and in order to increase the reliability of the survey, more surveys were applied and 400 valid surveys were evaluated.

\section{Selection of Inquiry Method}

Due to the fact that inquiries by interviews are safer and faster, an online survey with standard forms was used to determine the opinions of the individuals who constitute the population of the study about the use of open and green spaces in pandemic conditions.

\section{Preparation of the Survey}

A survey was prepared consisting of two parts, namely determining the views of Landscape Architects about urban open and green areas under epidemic conditions and socio-economic structure. The survey consist of a total of 29 questions including questions about socio-economic structure (12), the opinions about the practices (13) in outdoors areas where human mobility increases during the pandemic, the use of urban open and green areas in pandemic conditions, and human behavior in open and green areas (4).

\section{Pre-Testing the Survey and Correcting Error}

The survey form prepared was developed primarily in line with the opinions of experts in the fields of surveying, environment, urban open and green areas, and landscape planning. The survey was examined with experts under the titles of content, form, meaning, and evaluation. The preliminary surveys were applied with randomly selected 20 Landscape Architects and took their final form in line with the opinions obtained from these individuals.

\section{Application of the Survey}

Surveys were applied to Landscape Architects in the period of August-December 2020 in the electronic environment to get the views of Landscape Architects in different provinces on the Covid-19 pandemic.

\section{Evaluation of Survey Results}

The survey results were evaluated via IBM SPSS20 software. The survey includes 5 question types as single choice, multiple-choice, 3 choice/ranking, open-ended, and the level of agreement. The items in sections I and II were created with 3 options, multiple-choice, open-ended and ranking criteria to enable individuals to express their 
opinions on the subject more easily and for the purpose of the study.

The data obtained from the survey forms were coded and analyzed in IBM SPSS20 software. "Frequency Analysis" was used to determine the level and frequency of agreement in the questionnaire scales. In order to determine whether the comparison tests for 2 or more variables are parametric or not, a normality test was performed on the data set with the "Kolmogorov-Smirnov and Shapiro-Wilk Test" (Table 1).

Contingency tables that allow the comparison of variables and show the mutual sub-options of the binary variable together were used in data analysis The normality test was performed on the data set with the "KolmogorovSmirnov and Shapiro-Wilk Test" to determine whether the comparison tests for 2 or more variables were parametric or not. As a result of the analysis, it was seen that the data did not comply with the normal distribution, and the tests suitable for the purpose of the study were selected among the non-parametric tests and applied. The "MannWhitney U Test" was used for paired comparisons, and the "Kruskal-Wallis H Test" was used for comparing more than two variables (Griffith, 2010).

\section{Findings}

\section{Demographic Characteristics}

The demographic characteristics of the Landscape Architects who participated in the study were determined by frequency analysis and presented in Table 2 .

$67,3 \%$ of the Landscape Architects participating in the survey were female (269 people), and 32,8\% were male (131 people). While those with a bachelor's degree $(46,3 \%)$ showed the highest rate of participation, the participation rate of those with a Ph.D. degree was $30,3 \%$ and those with

Table 1. Normality distribution

\begin{tabular}{|c|c|c|c|}
\hline & Statistics & sd & $\mathbf{p}$ \\
\hline Opinions on the use of open and green areas and practices in the pandemic & 0,098 & 400 & $<0,001$ \\
\hline Opinions about the behaviour of people in open and green areas when they are around strangers & 0,094 & 400 & $<0,001$ \\
\hline
\end{tabular}

Table 2. Demographic characteristics of the participants of the survey

\begin{tabular}{|c|c|c|c|c|c|c|c|}
\hline & Group & $\mathbf{n}$ & Rate (\%) & & Group & n & Rate (\%) \\
\hline \multirow[t]{2}{*}{ Gender } & Female & 269 & 67,3 & Age & $22-30$ age & 170 & 42,5 \\
\hline & Male & 131 & 32,8 & & $31-40$ age & 139 & 34,8 \\
\hline \multirow[t]{3}{*}{ Education status } & Bachelor's degree & 185 & 46,3 & & $41-50$ age & 62 & 15,5 \\
\hline & Master's degree & 94 & 23,5 & & $51-60$ age & 25 & 6,3 \\
\hline & Ph.D. & 121 & 30,3 & & $>61$ age & 4 & 1,0 \\
\hline \multirow[t]{2}{*}{ Marital status } & Married & 184 & 46,0 & Membership of CLA* & Member & 257 & 64,3 \\
\hline & Single & 216 & 54,0 & & Not a member & 143 & 35,8 \\
\hline \multirow[t]{6}{*}{ Professional experience } & $0-5$ years & 149 & 37,3 & Income $\left(も^{* *}\right)$ & $<2.500$ & 33 & 8,3 \\
\hline & 6-10 years & 95 & 23,8 & & $2501-5000$ & 77 & 19,3 \\
\hline & $11-15$ years & 44 & 11,0 & & $5001-10000$ & 176 & 44,0 \\
\hline & $16-20$ years & 43 & 10,8 & & $10001-20000$ & 92 & 23,0 \\
\hline & $>21$ years & 52 & 13,0 & & $>20001$ & 6 & 1,5 \\
\hline & Non-response & 17 & 4,3 & & Non response & 16 & 4,0 \\
\hline \multirow[t]{8}{*}{ Faculty } & Agricultural & 205 & 51,2 & Working area & University & 126 & 31,5 \\
\hline & Forestry & 74 & 18,5 & & Office & 68 & 17,0 \\
\hline & Architecture & 82 & 20,5 & & Nursery & 21 & 5,3 \\
\hline & Architecture and Design & 12 & 3,0 & & Metropolitan municipality & 13 & 3,3 \\
\hline & Engineering and Architecture & 13 & 3,3 & & District Municipality & 32 & 8,0 \\
\hline & Fine Arts & 8 & 2,0 & & City Directorship & 3 & 0,8 \\
\hline & Non response & 5 & 1,3 & & Non-working & 66 & 16,5 \\
\hline & Abroad & 1 & 0,3 & & Other & 71 & 17,8 \\
\hline
\end{tabular}

${ }^{*}$ Chamber of Landscape Architects. **During the period of study, the average $\$ 1=$ varies between 6.93 and 7.84 も. 
a master's degree was $23,5 \% .54,0 \%$ of the participants were single. The youngest participant in the study was 22 years old (6 people) and the oldest was 65 years old, while the average age of the participants was 34,3 . The participation level of the $22-30$ age group $(42,5 \%)$ was the highest. The average professional experience of the individuals participating in the research was 10,8 years, and the rate of those who have been working for 0-5 years was $37,3 \%$. Participants with a household income of less than TRY 2500 were $8.3 \%$, while those with an income of TRY 20001 and above were 1.5\%. Those with an income of TRY 5 001-10 $000 \mathrm{TL}$ were at the highest rate (44,0\%). 64,3\% of the participants stated that they are registered to the TMMOB Chamber of Landscape Architects (Table 2). In line with the fact that Landscape Architecture education had started in Agriculture Faculties in Turkey, the participants were generally graduated from these faculties $(51,2 \%)$. As a result of departments established within different faculties and due to the fact that some departments within the Faculty of Agriculture and/or Forestry were transferred to the Faculty of Architecture (20,5\%), Architecture and Design (3,0\%), or Engineering and Architecture (3,3\%), the number of Landscape Architects graduating from different faculties is increasing day by day. When the working areas of Landscape Architects are examined, it is seen that 31,5\% of those participating in the survey work as academic staff in universities. While the rate of those who stated that they work in design offices was $17,0 \%$, the rate of those working in the municipality was $11,3 \%(8,0 \%$ province/ district municipality, 3,3\% metropolitan municipality) (Table 2). $43,6 \%$ of the Landscape Architects participating in the survey worked in various public institutions $(31,5 \%$ university, $11,3 \%$ municipality, $0,8 \%$ provincial directorate), $22,3 \%$ worked in offices and nurseries, and the rate of unemployed/nonworking Landscape Architects was 16,5\%. Landscape Architects who stated their workplace as other but did not write a description were $17,8 \%$.

Opinions on the Use and Applications of Open and

\section{Green Areas in Pandemic Conditions}

13 agreement level questions were asked to Landscape Architects about the use of urban open and green areas in pandemic conditions and their views about applications on this subject and descriptive analysis and non-parametric comparison tests were applied to the data obtained, respectively.

Frequency analysis was applied to evaluate the views of Landscape Architects regarding the use of open and green spaces and applications on this issue during the pandemic, and the level of agreement in the opinions presented to them was determined. According to the data obtained (Table 3 ), the highest rate of agreement (mean: 4,26 ) was calculated for Opinion 12, while the lowest rate of agreement (mean: 2,19) was calculated for Opinion 3.

The change of the views of the Landscape Architects participating in the survey on the use of open and green areas and the applications on this issue during the pandemic according to the gender of the participants was analyzed with the Mann Whitney $U$ test, and the findings are presented in Table 4. Accordingly, a statistically significant difference was observed in terms of agreement with Opinion 4, Opinion 8, and Opinion 13. According to the data obtained, female Landscape Architects showed a more indecisive tendency to the opinion that it is unnecessary to disinfect open and green areas compared to male Landscape Architects (mean: 2,04), as male Landscape Architects mostly said "I strongly disagree" (mean: 1,90). Male Landscape Architects also agreed with

Table 3. Participants' views on the use of open and green areas in pandemic conditions and applications on this issue (\%)

\begin{tabular}{|c|c|c|c|c|c|c|c|c|}
\hline & & $(1)^{*}$ & (2) & (3) & (4) & (5) & Std. D & Mean \\
\hline Opinion 1 & The pandemic has caused the cleaning and maintenance costs to increase. & 5,3 & 15,8 & 13,3 & 42,3 & 23,5 & 1,156 & 3,63 \\
\hline Opinion 2 & It should be kept open to support public health. & 3,8 & 6,5 & 16,5 & 35,5 & 37,8 & 1,068 & 3,97 \\
\hline Opinion 3 & It is a correct practice to close it to the public. & 33,5 & 32,0 & 20,5 & 9,5 & 4,5 & 1,135 & 2,19 \\
\hline Opinion 4 & Disinfection is unnecessary. & 3,3 & 8,3 & 15,0 & 29,0 & 44,5 & 1,104 & 4,03 \\
\hline Opinion 5 & Disinfection practices are harmful to creatures living in these areas. & 8,8 & 26,0 & 41,8 & 15,3 & 8,3 & 1,039 & 2,88 \\
\hline Opinion 6 & It is impossible to apply the physical distance rule. & 6,0 & 15,3 & 14,0 & 41,5 & 23,3 & 1,171 & 3,60 \\
\hline Opinion 7 & Physical distance rule cannot be applied in children's playgrounds. & 24,3 & 35,3 & 10,8 & 20,3 & 9,5 & 1,308 & 2,55 \\
\hline Opinion 8 & The risk of disease transmission from urban furniture is high. & 3,5 & 14,5 & 26,5 & 37,5 & 18,0 & 1,054 & 3,52 \\
\hline Opinion 9 & The risk of disease transmission from grass areas is high. & 17,8 & 39,8 & 31,3 & 10,0 & 1,3 & 0,930 & 2,37 \\
\hline Opinion 10 & Wind is effective in carrying sick droplets to humans. & 6,3 & 14,2 & 29,8 & 35,8 & 14,0 & 1,084 & 3,37 \\
\hline Opinion 11 & Rain is effective in carrying sick droplets to humans & 12,3 & 30,5 & 46,5 & 9,0 & 1,8 & 0,881 & 2,57 \\
\hline Opinion 12 & It is correct to leave food and water for street animals in these areas. & 4,8 & 3,8 & 6,0 & 31,8 & 53,8 & 1,053 & 4,26 \\
\hline Opinion 13 & Restriction signs made on grass areas are useful for social distance. & 5,3 & 10,0 & 12,5 & 37,0 & 35,3 & 1,156 & 3,87 \\
\hline
\end{tabular}

*(1) Strongly disagree; (2) Disagree; (3) Neutral; (4) Agree; (5) Strongly agree. 
Approaches of Landscape Architects to Applications for the Use of Open and Green Spaces in Conditions of Covid-19 Pandemic

Table 4. Evaluating the views on the use of open and green areas and applications on this issue during the pandemic according to gender

\begin{tabular}{|c|c|c|c|c|c|c|c|}
\hline & & & $\mathbf{n}$ & Mean* & $\mathbf{z}$ & Mann-Whitney U & $\mathbf{p}^{* *}$ \\
\hline \multirow[t]{2}{*}{ Opinion 1} & The pandemic has caused the cleaning and & Female & 184 & 3,57 & 0,177 & 17802,500 & 0,859 \\
\hline & maintenance costs to increase. & Male & 216 & 3,68 & & & \\
\hline \multirow[t]{2}{*}{ Opinion 2} & It should be kept open to support public health. & Female & 184 & 4,04 & 0,154 & 17778,000 & 0,877 \\
\hline & & Male & 216 & 3,90 & & & \\
\hline \multirow[t]{2}{*}{ Opinion 3} & It is a correct practice to close it to the public. & Female & 184 & 2,01 & 1,165 & 18832,500 & 0,244 \\
\hline & & Male & 216 & 2,34 & & & \\
\hline \multirow[t]{2}{*}{ Opinion 4} & Disinfection is unnecessary. & Female & 184 & 2,04 & 2,959 & 20637,500 & 0,003 \\
\hline & & Male & 216 & 1,90 & & & \\
\hline \multirow[t]{2}{*}{ Opinion 5} & Disinfection practices are harmful to creatures & Female & 184 & 3,03 & 0,576 & 18214,500 & 0,564 \\
\hline & living in these areas. & Male & 216 & 3,18 & & & \\
\hline \multirow[t]{2}{*}{ Opinion 6} & It is impossible to apply the physical distance rule. & Female & 184 & 2,26 & 0,077 & 17699,000 & 0,939 \\
\hline & & Male & 216 & 2,50 & & & \\
\hline \multirow[t]{2}{*}{ Opinion 7} & Physical distance rule cannot be applied in & Female & 184 & 3,52 & $-0,322$ & 17282,500 & 0,748 \\
\hline & children's playgrounds. & Male & 216 & 3,37 & & & \\
\hline \multirow[t]{2}{*}{ Opinion 8} & The risk of disease transmission from & Female & 184 & 3,36 & $-2,190$ & 15340,500 & 0,029 \\
\hline & urban furniture is high. & Male & 216 & 3,64 & & & \\
\hline \multirow[t]{2}{*}{ Opinion 9} & The risk of disease transmission from & Female & 184 & 2,21 & $-0,156$ & 17458,500 & 0,876 \\
\hline & grass areas is high. & Male & 216 & 2,50 & & & \\
\hline \multirow[t]{2}{*}{ Opinion 10} & Wind is effective in carrying sick droplets & Female & 184 & 3,23 & $-1,372$ & 16190,000 & 0,170 \\
\hline & to humans. & Male & 216 & 3,48 & & & \\
\hline \multirow[t]{2}{*}{ Opinion 11} & Rain is effective in carrying sick droplets & Female & 184 & 2,47 & $-1,613$ & 15988,000 & 0,107 \\
\hline & to humans. & Male & 216 & 2,66 & & & \\
\hline \multirow[t]{2}{*}{ Opinion 12} & It is correct to leave food and water for & Female & 184 & 4,05 & $-0,464$ & 17165,500 & 0,643 \\
\hline & street animals in these areas. & Male & 216 & 4,43 & & & \\
\hline \multirow[t]{2}{*}{ Opinion 13} & Restriction signs made on grass areas are & Female & 184 & 3,74 & $-2,259$ & 15291,000 & 0,024 \\
\hline & useful for social distance. & Male & 216 & 3,97 & & & \\
\hline
\end{tabular}

*(1) Strongly disagree; (2) Disagree; (3) Neutral; (4) Agree; (5) Strongly agree. ** $p \leq 0,05$.

Opinion 8 (mean: 3,64) and Opinion 13 (mean: 3,97) at higher levels.

When examining the differences in views of participants on the use of open and green areas during the Covid-19 pandemic and the applications about this issue based on the marital status of the participants, a statistically significant difference was found in participant' responses to Opinion 3, Opinion 6, Opinion 8, Opinion 9, Opinion 11, Opinion 12 and Opinion 13 based on their marital status and the level of agreement of single Landscape Architects were higher than married Landscape Aarchitects in all these statements levels (Table 5).

A statistically significant difference was observed in the responses to Opinion 2 and Opinion 4 between the participants' use of open and green spaces under epidemic conditions and the level of agreement in the opinion regarding the applications on this issue and whether they were a member of the trade association (Table 6). Landscape Architects who are members of the trade association show higher level of agreement than their colleagues who are not members of the trade association with the ideas that these areas should be kept open to the public during the Covid-19 pandemic and that it is unnecessary to disinfect these areas in order to support public health.

The education levels of the Landscape Architects who participated in the survey had a statistically significant effect on the responses to Opinion 1, Opinion 2, Opinion 4 and Opinion 5 (Table 7). Individuals with a Ph.D. degree stated that the pandemic increased the costs of cleaning and maintenance, that disinfection is unnecessary and is harmful to living beings, Landscape Architects with a master's degree were the least likely to agree with these views. The support for the idea about necessity to keep open and green spaces open to support public health increases in direct proportion to the education level of Landscape Architects.

The statistically significant relationship between the age group and the level of agreement of Landscape Architects with the use of open and green areas during the pandemic and applications on this issue is presented in Table 8. Accordingly, while Landscape Architects over 
Table 5. Evaluation of the views on the use of open and green areas during the pandemic and the applications in this regard based on the marital status

\begin{tabular}{|c|c|c|c|c|c|c|c|}
\hline & & & $\mathbf{n}$ & Mean* & $\mathbf{Z}$ & Mann-Whitney U & $\mathbf{p}^{* *}$ \\
\hline \multirow[t]{2}{*}{ Opinion 1} & The pandemic has caused the cleaning and & Married & 184 & 3,57 & 0,907 & 20867,000 & 0,364 \\
\hline & maintenance costs to increase. & Single & 216 & 3,68 & & & \\
\hline \multirow[t]{2}{*}{ Opinion 2} & It should be kept open to support public health. & Married & 184 & 4,04 & $-1,789$ & 17919,500 & 0,074 \\
\hline & & Single & 216 & 3,90 & & & \\
\hline \multirow[t]{2}{*}{ Opinion 3} & It is a correct practice to close it to the public. & Married & 184 & 2,01 & 3,020 & 23210,000 & 0,003 \\
\hline & & Single & 216 & 2,34 & & & \\
\hline \multirow[t]{2}{*}{ Opinion 4} & Disinfection is unnecessary. & Married & 184 & 2,04 & $-1,270$ & 18496,500 & 0,204 \\
\hline & & Single & 216 & 1,90 & & & \\
\hline \multirow[t]{2}{*}{ Opinion 5} & Disinfection practices are harmful to & Married & 184 & 3,03 & 1,162 & 21145,500 & 0,245 \\
\hline & creatures living in these areas. & Single & 216 & 3,18 & & & \\
\hline \multirow[t]{2}{*}{ Opinion 6} & It is impossible to apply the physical distance rule. & Married & 184 & 2,26 & 2,130 & 22212,500 & 0,033 \\
\hline & & Single & 216 & 2,50 & & & \\
\hline \multirow[t]{2}{*}{ Opinion 7} & Physical distance rule cannot be applied & Married & 184 & 3,52 & $-1,140$ & 18603,500 & 0,254 \\
\hline & in children's playgrounds. & Single & 216 & 3,37 & & & \\
\hline \multirow[t]{2}{*}{ Opinion 8} & The risk of disease transmission from urban & Married & 184 & 3,36 & 2,533 & 22672,000 & 0,011 \\
\hline & furniture is high. & Single & 216 & 3,64 & & & \\
\hline \multirow[t]{2}{*}{ Opinion 9} & The risk of disease transmission from & Married & 184 & 2,21 & 3,234 & 23407,500 & 0,001 \\
\hline & grass areas is high. & Single & 216 & 2,50 & & & \\
\hline \multirow[t]{2}{*}{ Opinion 10} & Wind is effective in carrying sick droplets to humans & Married & 184 & 3,23 & 1,950 & 22030,000 & 0,051 \\
\hline & & Single & 216 & 3,48 & & & \\
\hline \multirow[t]{2}{*}{ Opinion 11} & Rain is effective in carrying sick droplets to humans & Married & 184 & 2,47 & 2,121 & 22150,000 & 0,034 \\
\hline & & Single & 216 & 2,66 & & & \\
\hline \multirow[t]{2}{*}{ Opinion 12} & It is correct to leave food and water for street & Married & 184 & 4,05 & 3,352 & 23354,000 & 0,001 \\
\hline & animals in these areas. & Single & 216 & 4,43 & & & \\
\hline \multirow[t]{2}{*}{ Opinion 13} & Restriction signs made on grass areas are & Married & 184 & 3,74 & 1,980 & 22039,500 & 0,048 \\
\hline & useful for social distance. & Single & 216 & 3,97 & & & \\
\hline
\end{tabular}

*(1) Strongly disagree; (2) Disagree; (3) Neutral; (4) Agree; (5) Strongly agree. ** $p \leq 0,05$.

61 years of age showed the highest level of agreement with Opinion 3, Opinion 4 and Opinion 10, those with the lowest level of agreement were Landscape Architects in the 41-50 age group. Landscape Architects over 61 years of age agreed the most with Opinion 13, and Landscape Architects between the ages of 31-40 had the lowest level of agreement. The age group with the highest level of agreement with Opinion 6 and Opinion 7 was determined to be Landscape Architects between the ages of 51-60, while the lowest level of agreement was found in the 22-30 and 31-40 age groups, respectively. The age group that agreed with Opinion 8 at the highest level was the age range of 22-30, while the lowest level agreement was in the 41-50 age group. While Landscape Architects between the ages of 22-30 were most likely to agree with Opinion 12, those who showed the lowest level of agreement were Landscape Architects over 61 years old.

It is hereby seen that; attendants displayed meaningful differences statistically according to the faculties graduated, graduates of Faculty of Agriculture remained at a lower level for supporting Opinion 2, Opinion 3, Opinion 4 , and Opinion 13 compared to other faculty graduates, and the graduates of Faculty of Forestry displayed the lowest attendance for Opinion 8 (Table 9).

A statistically significant relationship was found between the professional experience periods of the Landscape Architects participating in the survey, and the level of agreement with Opinion 2 and Opinion 6 increases as the duration of professional experience increases. The Landscape Architects with lower professional experience showed a higher level of agreement with Opinion 4, Opinion 8, and Opinion 12 (Table 10).

According to the data obtained as a result of the analysis conducted to examine the change of views of Landscape Architects regarding the use of open and green areas during the pandemic the applications on this issue, a statistically significant difference was found in the level of agreement of the participants with Opinion 4 and Opinion 5 based on the units they work (Table 11). 
Table 6. Evaluation of the views on the use of open and green areas during the pandemic and the applications in this regard, based on the status of being registered with the Chamber of Landscape Architects

\begin{tabular}{|c|c|c|c|c|c|c|c|}
\hline & & & $\mathbf{n}$ & Mean* & $\mathbf{Z}$ & Mann-Whitney U & $\mathbf{p}^{* *}$ \\
\hline \multirow[t]{2}{*}{ Opinion 1} & The pandemic has caused the cleaning and & Yes & 257 & 3,59 & 0,739 & 19154,500 & 0,460 \\
\hline & maintenance costs to increase. & No & 143 & 3,69 & & & \\
\hline \multirow[t]{2}{*}{ Opinion 2} & It should be kept open to support public health. & Yes & 257 & 4,01 & $-2,273$ & 15990,500 & 0,023 \\
\hline & & No & 143 & 3,88 & & & \\
\hline \multirow[t]{2}{*}{ Opinion 3} & It is a correct practice to close it to the public. & Yes & 257 & 2,14 & 1,743 & 20228,500 & 0,081 \\
\hline & & No & 143 & 2,27 & & & \\
\hline \multirow[t]{2}{*}{ Opinion 4} & Disinfection is unnecessary. & Yes & 257 & 2,05 & $-2,054$ & 16236,000 & 0,040 \\
\hline & & No & 143 & 1,81 & & & \\
\hline \multirow[t]{2}{*}{ Opinion 5} & Disinfection practices are harmful to creatures & Yes & 257 & 3,11 & $-0,018$ & 18356,000 & 0,985 \\
\hline & living in these areas. & No & 143 & 3,12 & & & \\
\hline \multirow[t]{2}{*}{ Opinion 6} & It is impossible to apply the physical distance rule. & Yes & 257 & 2,36 & 0,939 & 19367,500 & 0,348 \\
\hline & & No & 143 & 2,44 & & & \\
\hline \multirow[t]{2}{*}{ Opinion 7} & Physical distance rule cannot be applied & Yes & 257 & 3,44 & $-0,082$ & 18288,000 & 0,935 \\
\hline & in children's playgrounds. & No & 143 & 3,44 & & & \\
\hline \multirow[t]{2}{*}{ Opinion 8} & The risk of disease transmission from urban & Yes & 257 & 3,44 & 1,798 & 20286,500 & 0,072 \\
\hline & furniture is high. & No & 143 & 3,65 & & & \\
\hline \multirow[t]{2}{*}{ Opinion 9} & The risk of disease transmission from grass & Yes & 257 & 2,36 & $-0,120$ & 18249,000 & 0,904 \\
\hline & areas is high. & No & 143 & 2,37 & & & \\
\hline \multirow[t]{2}{*}{ Opinion 10} & Wind is effective in carrying sick droplets to humans & Yes & 257 & 3,36 & $-0,250$ & 18109,500 & 0,803 \\
\hline & & No & 143 & 3,37 & & & \\
\hline \multirow[t]{2}{*}{ Opinion 11} & Rain is effective in carrying sick droplets to humans & Yes & 257 & 2,53 & 1,271 & 19688,500 & 0,204 \\
\hline & & No & 143 & 2,65 & & & \\
\hline \multirow[t]{2}{*}{ Opinion 12} & It is correct to leave food and water for street & Yes & 257 & 4,20 & 0,774 & 19148,500 & 0,439 \\
\hline & animals in these areas. & No & 143 & 4,36 & & & \\
\hline \multirow[t]{2}{*}{ Opinion 13} & Restriction signs made on grass areas are & Yes & 257 & 3,79 & 1,542 & 19999,000 & 0,123 \\
\hline & useful for social distance. & No & 143 & 4,00 & & & \\
\hline
\end{tabular}

*(1) Strongly disagree; (2) Disagree; (3) Neutral; (4) Agree; (5) Strongly agree. ** $p \leq 0,05$.

While Landscape Architects working in a nursery thought that disinfecting these areas was unnecessary with the highest level of agreement, while Landscape Architects working at universities had the lowest level of agreement in this regard. Likewise, Landscape Architects working at universities had the lowest level of agreement with the opinion that disinfection practices are harmful to living creatures in these areas.

\section{Evaluation of Outdoor Human Mobility and Behaviors} in the Pandemic

When the attendants were asked in which outdoor areas in cities the mobility of people tended to increase during the pandemic, they replied as the areas with the highest mobility were the sea coasts $(14,5 \%)$, parks $(12,8 \%)$ and main streets $(11,0 \%)$ (Figure 2$)$. The results obtained are

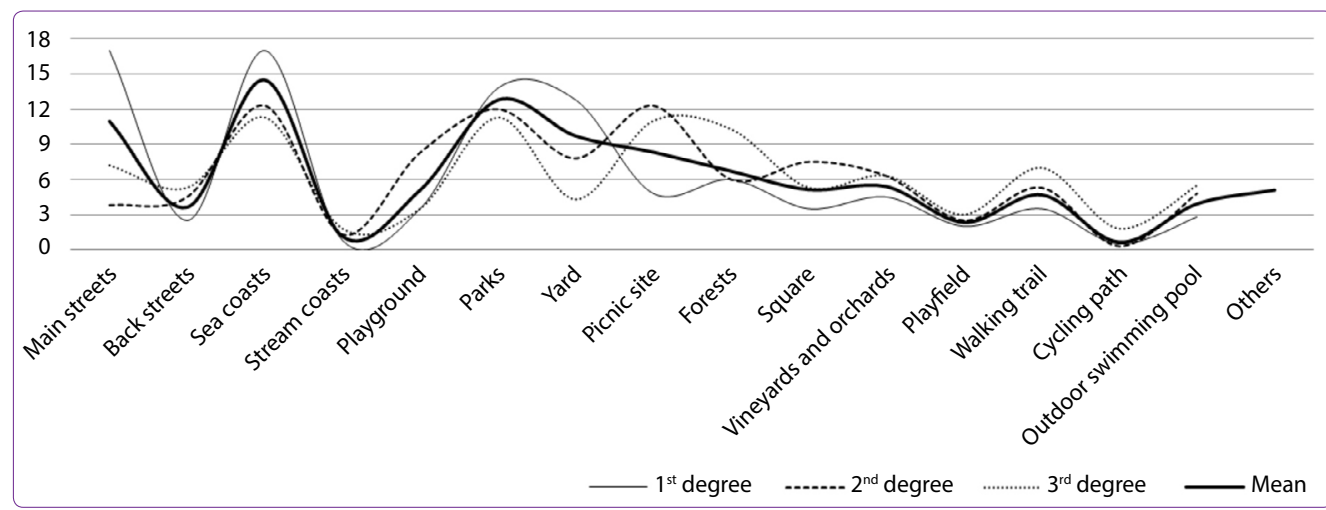

Figure 2. The outdoor areas in our cities where the human mobility tends to increase (\%). 
Table 7. Evaluation of the views on the use of open and green areas during the pandemic and the application on this issue based on the level of education

\begin{tabular}{|c|c|c|c|c|c|c|}
\hline & & & MEAN* & & Kruskal- & $\mathbf{p}^{* *}$ \\
\hline & & $\begin{array}{c}\text { BSC } \\
(n=185)\end{array}$ & $\begin{array}{c}\text { MSc } \\
(n=94)\end{array}$ & $\begin{array}{c}\text { PhD } \\
(n=121)\end{array}$ & & \\
\hline Opinion 1 & The pandemic has caused the cleaning and maintenance costs to increase. & 3,62 & 3,40 & 3,80 & 6,670 & 0,036 \\
\hline Opinion 2 & It should be kept open to support public health. & 3,85 & 3,92 & 4,18 & 8,179 & 0,017 \\
\hline Opinion 3 & It is a correct practice to close it to the public. & 2,32 & 2,11 & 2,04 & 5,628 & 0,060 \\
\hline Opinion 4 & Disinfection is unnecessary. & 1,90 & 1,71 & 2,25 & 13,186 & 0,001 \\
\hline Opinion 5 & Disinfection practices are harmful to creatures living in these areas. & 3,10 & 2,85 & 3,33 & 11,359 & 0,003 \\
\hline Opinion 6 & It is impossible to apply the physical distance rule. & 2,43 & 2,31 & 2,38 & 0,582 & 0,747 \\
\hline Opinion 7 & Physical distance rule cannot be applied in children's playgrounds. & 3,48 & 3,32 & 3,47 & 0,904 & 0,636 \\
\hline Opinion 8 & The risk of disease transmission from urban furniture is high. & 3,52 & 3,50 & 3,52 & 0,219 & 0,896 \\
\hline Opinion 9 & The risk of disease transmission from grass areas is high. & 2,34 & 2,25 & 2,51 & 4,659 & 0,097 \\
\hline Opinion 10 & Wind is effective in carrying sick droplets to humans. & 3,36 & 3,20 & 3,51 & 5,000 & 0,082 \\
\hline Opinion 11 & Rain is effective in carrying sick droplets to humans & 2,58 & 2,45 & 2,65 & 3,121 & 0,210 \\
\hline Opinion 12 & It is correct to leave food and water for street animals in these areas. & 4,30 & 4,24 & 4,19 & 2,040 & 0,361 \\
\hline Opinion 13 & Restriction signs made on grass areas are useful for social distance. & 3,82 & 3,88 & 3,93 & 0,749 & 0,688 \\
\hline
\end{tabular}

*(1) Strongly disagree; (2) Disagree; (3) Neutral; (4) Agree; (5) Strongly agree. ** $p \leq 0,05$.

Table 8. Evaluation of the views on the use of open and green areas and the applications on this issue during the pandemic based on the age groups

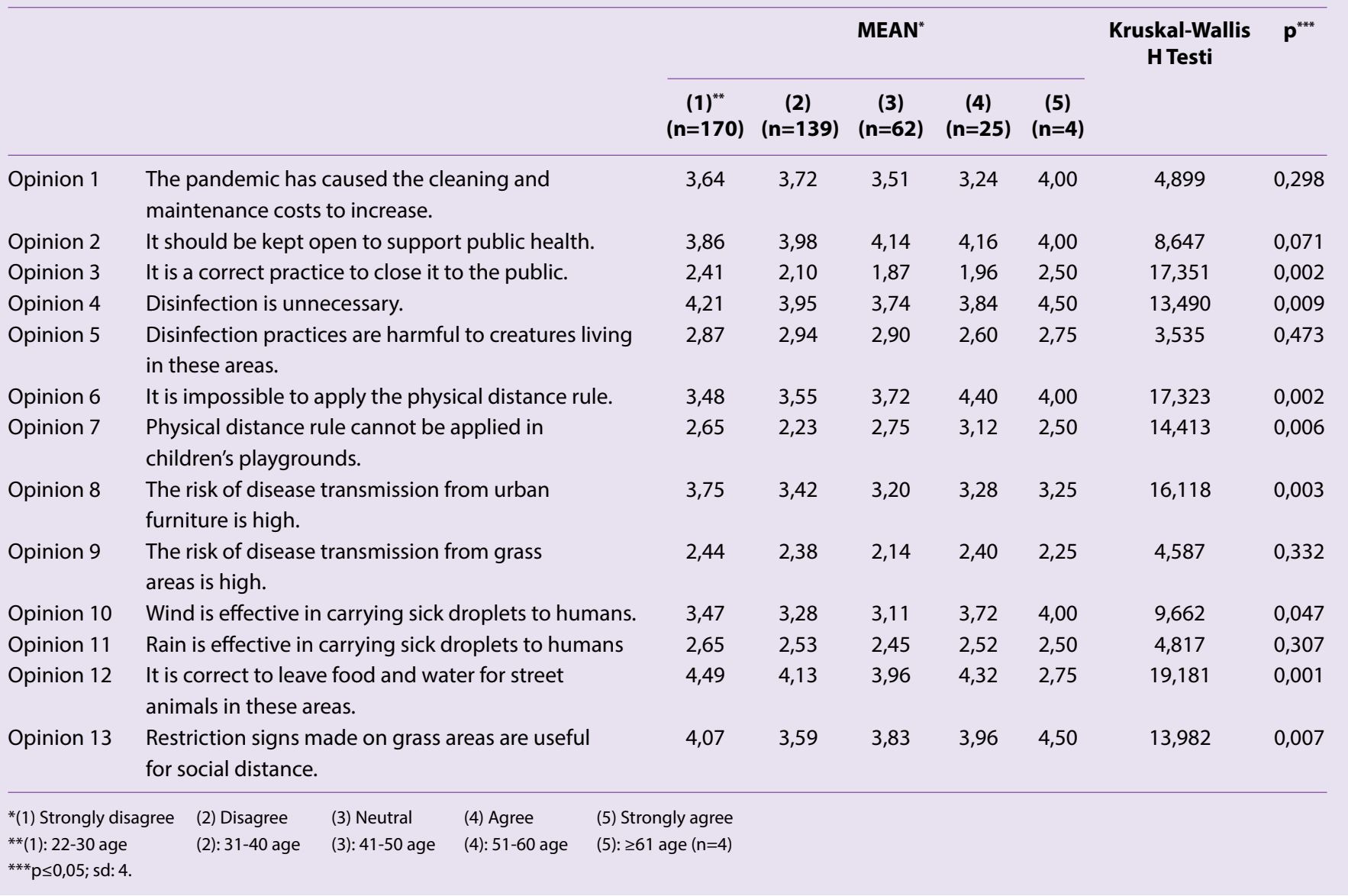


Table 9. Evaluation of the views on the use of open and green areas during the pandemic and the applications on this issue based on the faculties of graduation

\begin{tabular}{|c|c|c|c|c|c|c|c|}
\hline & & \multicolumn{4}{|c|}{ MEAN* } & \multirow{2}{*}{$\begin{array}{c}\text { Kruskal- } \\
\text { Wallis } \\
\text { H Test }\end{array}$} & \multirow[t]{2}{*}{$\mathbf{p}^{* *}$} \\
\hline & & $\begin{array}{l}\text { Agricultural } \\
(n=205)\end{array}$ & $\begin{array}{l}\text { Forestry } \\
(n=74)\end{array}$ & $\begin{array}{l}\text { Architecture } \\
\quad(n=82)\end{array}$ & $\begin{array}{l}\text { Other } \\
(n=39)\end{array}$ & & \\
\hline Opinion 1 & $\begin{array}{l}\text { The pandemic has caused the cleaning and } \\
\text { maintenance costs to increase. }\end{array}$ & 3,50 & 3,74 & 3,79 & 3,71 & 5,509 & 0,138 \\
\hline Opinion 2 & It should be kept open to support public health. & 4,09 & 3,87 & 3,92 & 3,56 & 12,046 & 0,007 \\
\hline Opinion 3 & It is a correct practice to close it to the public. & 2,02 & 2,27 & 2,32 & 2,66 & 12,500 & 0,006 \\
\hline Opinion 4 & Disinfection is unnecessary. & 3,90 & 3,94 & 4,28 & 4,35 & 13,602 & 0,004 \\
\hline Opinion 5 & $\begin{array}{l}\text { Disinfection practices are harmful to creatures } \\
\text { living in these areas. }\end{array}$ & 2,77 & 3,01 & 2,96 & 3,05 & 7,123 & 0,068 \\
\hline Opinion 6 & It is impossible to apply the physical distance rule. & 3,73 & 3,62 & 3,46 & 3,20 & 6,773 & 0,080 \\
\hline Opinion 7 & $\begin{array}{l}\text { Physical distance rule cannot be applied in } \\
\text { children's playgrounds. }\end{array}$ & 2,66 & 2,29 & 2,62 & 2,30 & 7,428 & 0,059 \\
\hline Opinion 8 & $\begin{array}{l}\text { The risk of disease transmission from urban } \\
\text { furniture is high. }\end{array}$ & 3,43 & 3,37 & 3,59 & 4,07 & 13,815 & 0,003 \\
\hline Opinion 9 & The risk of disease transmission from grass areas is high. & 2,38 & 2,25 & 2,31 & 2,66 & 4,048 & 0,256 \\
\hline Opinion 10 & Wind is effective in carrying sick droplets to humans. & 3,35 & 3,32 & 3,46 & 3,33 & 0,523 & 0,914 \\
\hline Opinion 11 & Rain is effective in carrying sick droplets to humans & 2,47 & 2,68 & 2,68 & 2,66 & 6,095 & 0,107 \\
\hline Opinion 12 & $\begin{array}{l}\text { It is correct to leave food and water for street } \\
\text { animals in these areas. }\end{array}$ & 4,22 & 4,05 & 4,40 & 4,53 & 6,104 & 0,107 \\
\hline Opinion 13 & $\begin{array}{l}\text { Restriction signs made on grass areas are useful } \\
\text { for social distance. }\end{array}$ & 3,67 & 4,00 & 4,12 & 4,12 & 11,070 & 0,011 \\
\hline
\end{tabular}

*(1) Strongly disagree; (2) Disagree; (3) Neutral; (4) Agree; (5) Strongly agree. ** $\mathrm{p} \leq 0,05$; sd:3.

similar when compared with the data of Our World in data (2021). As a matter of fact, according to these data, with the controlled social life that started after the restriction period in park areas, there was an increase of visitors at the rate of $41 \%$.

Landscape Architects' observations of outdoor human behavior are important for the sustainability of their work. Hence, during the landscape analysis, they obtain a result by observing the characteristics of the area as well as the behavior of the inhabitants. Based on this professional

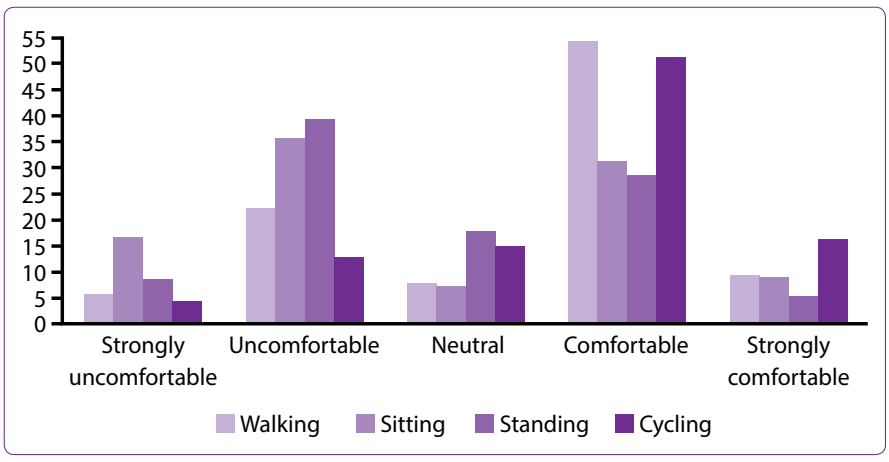

Figure 3. Behaviors of people in open and green areas with a stranger (\%). characteristic of Landscape Architects, participants in the study were asked to evaluate the behavior of people outdoors, considering the pandemic conditions. Accordingly, they observed that people were comfortable walking $(54,3 \%)$ and cycling $(51,2 \%)$ with other people in open and green areas, and they were uncomfortable while sitting $(35,5 \%)$ and standing $(39,3 \%)$ (Figure 3). Therefore, it can be concluded that people are comfortable while they are moving and uncomfortable when they are static.

\section{Conclusion}

The Covid-19 pandemic has revived the relationship of people living in cities with natural areas, parks, and open areas, and showed that Landscape Architects need to play an active role not only in the design of open and green areas but also in the planning of open and green space systems in cities. Outdoor activities in the city are limited to some open and green areas such as walking areas, bicycle paths, sports fields, parks, and forests. Even in limited areas, an individual is expected to benefit from the activity $\mathrm{s} / \mathrm{he}$ is doing at the optimum level. However, reasons such as the insufficient size of such areas, restriction/ limitation of human activities, an insufficient amount of 
Table 10. Evaluation of the views on the use of open and green areas during the pandemic and the applications on this issue based on the duration of professional experience

\begin{tabular}{|c|c|c|c|c|c|c|c|c|c|}
\hline & & \multicolumn{6}{|c|}{ MEAN* } & \multirow{2}{*}{$\begin{array}{c}\text { Kruskal- } \\
\text { Wallis } \\
\text { H Test }\end{array}$} & \multirow[t]{2}{*}{$\mathbf{p}^{* *}$} \\
\hline & & $\begin{array}{c}0-5 \\
\text { year } \\
(n=185)\end{array}$ & $\begin{array}{c}6-10 \\
\text { year } \\
(n=94)\end{array}$ & $\begin{array}{c}11-15 \\
\text { year } \\
(n=121)\end{array}$ & $\begin{array}{l}16-20 \\
\text { year } \\
(n=43)\end{array}$ & $\begin{array}{c}>21 \\
\text { year } \\
(n=52)\end{array}$ & $\begin{array}{c}\text { Non } \\
\text { response } \\
(n=17)\end{array}$ & & \\
\hline Opinion 1 & $\begin{array}{l}\text { The pandemic has caused the cleaning and } \\
\text { maintenance costs to increase. }\end{array}$ & 3,73 & 3,69 & 3,47 & 3,67 & 3,25 & 3,76 & 6,486 & 0,262 \\
\hline Opinion 2 & $\begin{array}{l}\text { It should be kept open to support } \\
\text { public health. }\end{array}$ & 3,86 & 3,89 & 4,00 & 4,09 & 4,07 & 4,58 & 14,535 & 0,013 \\
\hline Opinion 3 & It is a correct practice to close it to the public. & 2,34 & 2,29 & 1,95 & 2,06 & 1,90 & 2,11 & 13,007 & 0,023 \\
\hline Opinion 4 & Disinfection is unnecessary. & 4,29 & 3,97 & 3,79 & 3,90 & 3,61 & 4,23 & 19,641 & 0,001 \\
\hline Opinion 5 & $\begin{array}{l}\text { Disinfection practices are harmful to } \\
\text { creatures living in these areas. }\end{array}$ & 3,01 & 2,76 & 2,88 & 2,86 & 2,78 & 2,70 & 4,813 & 0,439 \\
\hline Opinion 6 & $\begin{array}{l}\text { It is impossible to apply the physical } \\
\text { distance rule. }\end{array}$ & 3,41 & 3,54 & 3,65 & 3,88 & 3,88 & 3,94 & 13,413 & 0,020 \\
\hline Opinion 7 & $\begin{array}{l}\text { Physical distance rule cannot be applied } \\
\text { in children's playgrounds. }\end{array}$ & 2,52 & 2,23 & 2,50 & 2,20 & 3,00 & 2,76 & 10,797 & 0,056 \\
\hline Opinion 8 & $\begin{array}{l}\text { The risk of disease transmission from } \\
\text { urban furniture is high. }\end{array}$ & 3,78 & 3,46 & 3,56 & 3,34 & 3,07 & 3,17 & 20,563 & 0,001 \\
\hline Opinion 9 & $\begin{array}{l}\text { The risk of disease transmission from } \\
\text { grass areas is high. }\end{array}$ & 2,45 & 2,47 & 2,20 & 2,18 & 2,32 & 2,11 & 6,116 & 0,295 \\
\hline Opinion 10 & $\begin{array}{l}\text { Wind is effective in carrying sick } \\
\text { droplets to humans. }\end{array}$ & 3,48 & 3,35 & 3,31 & 3,18 & 3,19 & 3,52 & 4,018 & 0,547 \\
\hline Opinion 11 & $\begin{array}{l}\text { Rain is effective in carrying sick } \\
\text { droplets to humans }\end{array}$ & 2,70 & 2,45 & 2,61 & 2,55 & 2,42 & 2,52 & 8,596 & 0,126 \\
\hline Opinion 12 & $\begin{array}{l}\text { It is correct to leave food and water } \\
\text { for street animals in these areas. }\end{array}$ & 4,50 & 4,35 & 3,95 & 3,76 & 4,11 & 4,05 & 15,851 & 0,007 \\
\hline Opinion 13 & $\begin{array}{l}\text { Restriction signs made on grass areas } \\
\text { are useful for social distance. }\end{array}$ & 4,01 & 3,84 & 3,63 & 3,62 & 3,76 & 4,29 & 6,772 & 0,238 \\
\hline
\end{tabular}

*(1) Strongly disagree; (2) Disagree; (3) Neutral; (4) Agree; (5) Strongly agree." $p \leq 0,05$; sd:5.

open and green areas per person make it inevitable that the expected benefit is far below the optimum level. Based on the responses to the survey, the data regarding the lack of social distance indicate that the green areas are insufficient and small. Besides, in addition to special factors such as age, gender, and health status in increasing the level of physical activity of the individual, the role of easy and effective access to these areas, especially with the function and opportunities provided by these areas, is quite high. The variety of opportunities provided to the user by open and green areas that offer significant physical activity opportunities in cities is also among the factors that determine the user profile.

The Covid-19 pandemic has permanently changed people's relationships with open and green spaces. One of its most direct effects on people's daily lives is the problem of access to public parks, and difficulties are encountered in the implementation of the social distance rule in these areas. Especially, the fact that the number, size, and density of green areas in cities are not at the desired level has been one of the important problems encountered in the battle against the pandemic. Furthermore, the population density in cities is also one of the problems encountered in the implementation of the social distance rule in areas such as streets, squares, and parks. It is possible to say that the population density in city centers, especially in metropolitan cities, makes it difficult to apply the social distance rule as the increase in the number of cases for a certain period of time indicates. This situation requires street designs that take public health into account in urban areas. The use of natural-local plants to increase the green texture on the roads is an important aspect to remember in this design.

For the first time in our country, on March 27, 2020, with the "Supplementary Circular on Parks, Recreation 
Table 11. Evaluation of the views on the use of open and green areas during the pandemic and the applications on this issue based on the units of employment

\begin{tabular}{|c|c|c|c|c|c|c|c|c|c|}
\hline & & \multicolumn{6}{|c|}{ MEAN $^{*}$} & \multirow{2}{*}{$\begin{array}{l}\text { Kruskal- } \\
\text { Wallis } \\
\text { H Test }\end{array}$} & \multirow[t]{2}{*}{$\mathbf{p}^{* *}$} \\
\hline & & $\begin{array}{c}\text { Local } \\
\text { government } \\
(n=48)\end{array}$ & $\begin{array}{l}\text { University } \\
\text { working } \\
(n=126)\end{array}$ & $\begin{array}{l}\text { Office } \\
(n=68)\end{array}$ & $\begin{array}{c}\text { Nursery } \\
(n=21)\end{array}$ & $\begin{array}{l}\text { Non- } \\
(n=66)\end{array}$ & $\begin{array}{l}\text { Other } \\
(n=71)\end{array}$ & & \\
\hline Opinion 1 & $\begin{array}{l}\text { The pandemic has caused the cleaning } \\
\text { and maintenance costs to increase. }\end{array}$ & 3,87 & 3,75 & 3,48 & 3,33 & 3,56 & 3,53 & 5,959 & 0,310 \\
\hline Opinion 2 & $\begin{array}{l}\text { It should be kept open to support } \\
\text { public health. }\end{array}$ & 4,02 & 4,06 & 4,07 & 3,38 & 3,95 & 3,85 & 9,399 & 0,094 \\
\hline Opinion 3 & $\begin{array}{l}\text { It is a correct practice to close } \\
\text { it to the public. }\end{array}$ & 2,33 & 2,11 & 2,11 & 2,61 & 2,21 & 2,16 & 4,204 & 0,520 \\
\hline Opinion 4 & Disinfection is unnecessary. & 3,91 & 3,80 & 4,19 & 4,52 & 4,04 & 4,19 & 15,101 & 0,010 \\
\hline Opinion 5 & $\begin{array}{l}\text { Disinfection practices are harmful } \\
\text { to creatures living in these areas. }\end{array}$ & 2,79 & 2,69 & 3,04 & 3,04 & 2,75 & 3,19 & 13,696 & 0,018 \\
\hline Opinion 6 & $\begin{array}{l}\text { It is impossible to apply the } \\
\text { physical distance rule. }\end{array}$ & 3,56 & 3,61 & 3,58 & 2,90 & 3,60 & 3,85 & 10,435 & 0,064 \\
\hline Opinion 7 & $\begin{array}{l}\text { Physical distance rule cannot be } \\
\text { applied in children's playgrounds. }\end{array}$ & 2,43 & 2,40 & 2,50 & 2,66 & 2,48 & 2,98 & 8,949 & 0,111 \\
\hline Opinion 8 & $\begin{array}{l}\text { The risk of disease transmission } \\
\text { from urban furniture is high. }\end{array}$ & 3,31 & 3,51 & 3,58 & 3,71 & 3,59 & 3,47 & 3,959 & 0,555 \\
\hline Opinion 9 & $\begin{array}{l}\text { The risk of disease transmission } \\
\text { from grass areas is high. }\end{array}$ & 2,25 & 2,41 & 2,35 & 2,42 & 2,36 & 2,39 & 1,575 & 0,904 \\
\hline Opinion 10 & $\begin{array}{l}\text { Wind is effective in carrying sick } \\
\text { droplets to humans. }\end{array}$ & 3,20 & 3,46 & 3,27 & 3,42 & 3,53 & 3,23 & 3,875 & 0,581 \\
\hline Opinion 11 & $\begin{array}{l}\text { Rain is effective in carrying sick } \\
\text { droplets to humans }\end{array}$ & 2,52 & 2,67 & 2,44 & 2,85 & 2,57 & 2,47 & 5,484 & 0,360 \\
\hline Opinion 12 & $\begin{array}{l}\text { It is correct to leave food and water } \\
\text { for street animals in these areas. }\end{array}$ & 4,14 & 4,13 & 4,26 & 4,61 & 4,51 & 4,21 & 10,744 & 0,057 \\
\hline Opinion 13 & $\begin{array}{l}\text { Restriction signs made on grass } \\
\text { areas are useful for social distance. }\end{array}$ & 3,52 & 3,91 & 3,58 & 4,19 & 4,00 & 4,08 & 8,789 & 0,118 \\
\hline
\end{tabular}

*(1) Strongly disagree; (2) Disagree; (3) Neutral; (4) Agree; (5) Strongly agree. " $p \leq 0,05$; sd:5.

Areas, Picnic Areas Within the Scope of Combating the Coronavirus Pandemic", it was prohibited for the citizens in provinces and districts to participate in activities such as picnic, fishing, exercising, walking etc. on the beaches, recreation areas, archaeological sites, picnic areas until the struggle against the pandemic is successful and it has been decided that these measures can be extended to weekdays depending on the situation of the provinces and districts (T.R. Ministry of Interior, 2020). Following this circular, various discussions on the use of open and green spaces arose and new measures were emphasized. In this context, disinfection of open and green areas has come to the fore and medical microbiologist Topkaya (2020) stated that the application of disinfectants to open areas such as parks and gardens is unnecessary and harms the ecological environment. Within the scope of the research, it was concluded that Landscape Architects defended the view that open and green areas should be opened to use to support public health during the Covid-19 pandemic with certain regulations. Although the participants stated that the pandemic increased cleaning and maintenance costs in open and green areas, they share the opinion that these areas should be disinfected, especially due to urban furniture. However, it is understood from the indecisive answers that they do not have information about the effects of the disinfection materials on living creatures in the area. While this situation varies according to the demographic characteristics of the individuals, it generally reveals the lack of experience in practice in terms of health and ecology sciences of the landscape architecture profession. The fact that Landscape Architects with a Ph.D. degree agree that disinfection practices will harm living creatures in these areas while those with a master's degree have the lowest level of agreement on this issue shows that this may be 
related to the fields of expertise of individuals. Frederick Law Olmsted, the founder of the landscape architecture profession, served as the Secretary General of the American Health Commission as well as landscape architecture and participated in studies on pandemics (Africa et al., 2020). Although there is a consensus on the fact that more effective solutions can be produced with members from different professional disciplines in scientific committees in combating pandemics, it is criticized that even healthcare professionals cannot be fully represented in the scientific board established in our country.

With the Covid-19 pandemic, on the one hand, prohibitions on the use of open and green areas and efforts to create physical distance with markings on green areas, on the other hand, intense crowds in areas where there is no control, reveals the necessity that working groups of related professions, especially Landscape Architects, need to show special effort. It has been understood that prolonged isolation and the confusion of lockdown and opening up exhausts people, therefore the need for participation in outdoor activities and the need for urban open and green spaces has increased. All these have revealed the necessity of establishing an accessible green area system of sufficient size throughout the city, compatible with the natural structure in cities. Landscape Architects participating in the study stated that the physical distance rule can be applied in open and green areas, but this is not possible in children's playgrounds, and markings on grass areas are useful. The change in human behaviors by cities during the pandemic in our country is partially understood from the number of cases. Therefore, measures to be taken in open and green areas should be handled on the basis of the characteristics of the cities. With the spread of the Covid-19 pandemic across the world, various studies are being made for providing opportunities for bicycle transportation, creating isolated spaces in parks through vegetative design (Holland, 2020), increasing access to open and green areas for people of all groups (O'Connor, 2020), using local plant species in open and green areas to strengthen people's immune systems (Foley, 2020), and the establishment of interconnected public-benefit parks in cities (LeBrasseur, 2020; Africa et all., 2020; Surico, 2020). As a result of the study conducted by Venter et al. (2020) in Oslo (Norway) with a population of 690 thousand, it is estimated that with the normalization process that the daily total recreational activity rate increased by $291 \%$ ( 86 thousand new events) compared to the same period average of the last 3 years. Researchers have found that the activity of both pedestrians (walking, running) and cyclists increased on trails with green areas. Despite the density in green areas, it is possible to maintain social distance compared to closed areas, suggesting that green areas play a role in indirectly reducing the spread of the Covid-19 pandemic.
There have been changes in the outdoor mobility of people during the epidemic period. In general, as in all countries, a remarkable increase in the use of parks is observed in our country depending on the season. Landscape Architects participating in the study observed that human mobility increased in areas such as seashore and parks, and they were comfortable when in motion (walking and cycling) in open and green areas. There are several studies on the positive effects of urban green spaces on people's physical and mental health and the environment. (Akpınar, 2019; Chiesura, 2004; EEA, 2012; Jones et al., 2012; Önder and Polat, 2012; Kabisch et al., 2015; Ferrini and Gori, 2020). However, no studies directly related to its effectiveness in the period of epidemic diseases have been found. During the Civil War, Olmsted, the founder of the landscape architecture profession, worked in the US Health Commission to protect the health of soldiers in camps and reduce illness (by initiating policies for selecting appropriate campsites, drainage and disposal of waste, ventilation of tents, and food preparation). Olmsted's understanding of the connection of areas, disease control, and public health has directly influenced his landscape architecture career and the design of many urban park systems. For example, the design for the interconnected parks that make up Boston's Emerald Necklace can be regarded as the first example of the green infrastructure concept. Olmsted highlighted the importance of plants by stating that "the air is disinfected with sunlight and leaves", regarding boulevards with trees he designed for Central Park (Le Brasseur, 2020).

As a result, it is important for Landscape Architects, who assume important roles in the planning, design, implementation, and sustainability of open and green spaces in the city, to develop new insights into the effects on cities and urban environments and the characteristics of urban areas during and after the pandemic. It is thought that it is important for Landscape Architects to create a system in harmony with the natural structure of the city and in connection with the surrounding natural ecosystems and to work in a vegetative design approach that represents the ecosystem in which the city is located in the arrangement of open and green areas for combatting pandemics. Also, on the basis of the Covid-19 pandemic, the participation of Landscape Architects in educational activities under the leadership of the chamber of Landscape Architects on the fight against natural disasters and other mass problems and protection of natural ecosystems based on the experience of pandemics will ensure large masses to understand the dimensions of the profession.

\section{References}

Africa, J., Ruane, C., Hilderbrand, G., \& Reed, C. (2020). Parks are essential - especially during the coronavirus pandem- 
ic. https://www.bostonglobe.com/ 2020/05/05/opinion/ parks-are-essential-especially-during-coronavirus-pandemic/ Erişim=06 Mayıs 2020

Akpınar, A. (2019). Kentsel yeşil alanların kalitesinin insan sağlığı ve fiziksel aktivitesi üzerindeki etkisinin incelenmesi. Artvin Çoruh Üniversitesi Orman Fakültesi Dergisi, 20(1), 36-46.

Anguluri, R., \& Narayanan, P. (2017). Role of green space in urban planning: Outlook towards smart cities. Urban Forestry \& Urban Greening, 25, 58-65.

Anonymous, (2020). https://www.history.com/news/cholerapandemic-new-york-city-london-paris-green-space (Erişim Tarihi: 16.06.2020)

Baş, T. (2001). Anket: anket nasıl hazırlanır?: anket nasıl uygulanır?: anket nasıl uygulanır?. Seçkin yayıncılık.

Berman, M. (2020). Why time outdoors is crucial to your health, even during the coronavirus pandemic. https://news.uchicago.edu/story/why-time-outdoors-crucial-your-health-evenduring-coronavirus-pandemic Erişim=06 Nisan 2020

Brooks, S. K., Webster, R. K., Smith, L. E., Woodland, L., Wessely, S., Greenberg, N., \& Rubin, G. J. (2020). The psychological impact of quarantine and how to reduce it: rapid review of the evidence. The lancet, 395(10227), 912-920.

Caria, F., Fiorin, G., Gomez, H., Hensel, I., Jachimowicz, K. T., Reutskaja, R., \& Witte, Y. (2020). Measuring Worldwide COVID-19 Attitudes and Beliefs. https://www.eeassoc.org/ doc/upload/Measuring_Worldwide20200408184335.pdf

Chiesura, A. (2004). The role of urban parks for the sustainable city. Landscape and Urban Planning (68) 129-138.

Cranz, G., (2000). Changing roles of urban park: From pleasure garden to open space. San Francisco Planning and Urban Research Association, SPUR, USA

Davies, S., (2020). Maze parks to micromarkets: How coronavirus could bring cities closer to home. Thomson Reuters Foundation News. https://news.trust.org/item/202005040418576sxb7/ Erişim=04 Mayıs 2020

EEA (European Environment Agency) (2012). Urban adaptation to climate change in Europe hallenges and opportunities for cities together with supportive national and European policies. ISBN 978-92-9213-308-5.

Ferrini, F., \& Gori, A. (2020). Cities after COVID-19: how trees and green infrastructures can help shaping a sustainable future. Ri-Vista, DOI: 10.13128/rv-8553 - www.fupress.net/index. php/ri-vista/

Foley, M., (2020). Rejuvenate green spaces to fight rise of immune diseases, experts say. https://www.smh.com.au/ politics/federal/rejuvenate-green-spaces-to-fight-rise-ofimmune-diseases-experts-say-20200526-p54woz.html Erişim=27 Mayıs 2020

Griffith, A., (2010). SPSS For Dummies, Second Eddition, Wiley Publishing Inc. http://www.academia.dk/BiologiskAntropologi/Epidemiologi/PDF/SPSS_For_Dummies_2ndEd.pdf, Erişim tarihi: 15.02.2021.

Holland, O., (2020). Our cities may never look the same again after the pandemic. https://edition.cnn.com/style/article/ cities-design-coronavirus/index.html Erişim=10 Mayıs 2020

Jones H. P., Hole D. G., \& Zavaleta E. S. (2012). Harnessing nature to help people adapt to climate change. Nature Climate Change. Published Online: 26 June 2012 |DOI: 10.1038/ NCLIMATE1463
Kabisch N., Quershi S., \& Haase D. (2015). Human environment interactions in urban green spaces-A systematic review of contemporary issues and prospects for future research. Environmental Impact Assessment Review 50 (2015) 25-34.

Le Brasseur, R., (2020). Public parks matter more than ever during a pandemic. https://www.ecowatch.com/public-parks-pandemic-2646075681.html?rebelltitem=3\#rebelltitem3 Erişim=24 Mayıs 2020

Maruani T., \& Amit-Cohen I. (2007). Open space planning models: A review of approaches and methods. Landscape and Urban Planning 81 (2007) 1-13.

O'Connor, E., (2020). Public space plays vital role in pandemic. https://gehlpeople.com/blog/public-space-plays-vital-rolein-pandemic/) Erişim=07 Mayıs 2020

Önder, S., \& Polat, A. T. (2012). Kentsel açık-yeşil alanların kent yaşamındaki yeri ve önemi. Kentsel Peyzaj Alanlarının Oluşumu ve Bakım Esasları Semineri, 19, 73-96.

Our World in Data, (2021). How did the number of visitors change since begining of the pandemic Turkey. https://ourworldindata.org/grapher/changes-visitors-covid

SCBD, (2013). Secretariat of the Convention on Biological Diversity. Cities and Biodiversity Outlook (ISBN 92-9225-432-2) is an open access publication, subject to the terms of the Creative Commons Attribution License (http://creativecommons.org/ licenses/by-nc/3.0/).

Surico, J., (2020). The Power of Parks in a Pandemic. https:// www.citylab.com/perspective/2020/04/coronavirus-nature-city-park-funding-accessibility-location/609697/ Erişim=09 Nisan 2020

T.R. Ministry of Health (T.C. Sağlık Bakanlığı), (2021). Covid-19 Bilgilendirme Platformu. https://covid19.saglik.gov.tr/TR68443/covid-19-durum-raporu.html Erişim= 15 Mart 2021

T.R. Ministry of Interior (T.C. İçişleri Bakanlığı), (2020). Koronavirüs Salgını ile Mücadele Kapsamında Park, Mesire, Piknik Yerleri İle İlgili Ek Genelge. https://www.icisleri.gov.tr/koronavirus-salgini-ile-mucadele-kapsaminda-park-mesire-piknik-yerleri-ile-ilgili-ek-genelge Erişim=29 Mart 2020

TMMOB Chamber of Landscape Architects, (2020). Union of Chambers of Turkish Engineers and Architects (TMMOB) Chamber of Landscape Architects (TMMOB Peyzaj Mimarları Odası). 2020 yılı üye sayısı. https://www.peyzaj.org.tr/hakkimizda/istatistikler/rapor9.php

Topkaya, A.E., (2020). "Açık alanlarda dezenfektan kullanımı gereksizdir" Sözcü Gazetesi https://www.sozcu.com.tr/2020/ gundem/acik-alanlarda-dezenfektan-kullanilmasi-gereksizdir-5680294/ Erişim=15 Mart 2020

TUIK, (2021). Türkiye İstatistik Kurumu, İstatistik Veri Portalı, Şehir-Köy Nüfus Oranı 1927-2020. https://data.tuik.gov.tr/ Search/Search?text=n\%C3\%BCfus (Erişim Tarihi: 12.03.2021).

Venter, Z., Barton, D., Gundersen, V., Figari, H., \& Nowell, M. (2020). Urban nature in a time of crisis: recreational use of green space increases during the COVID-19 outbreak in Oslo, Norway. Environmental Research Letters, Volume 15, No: 10

WHO (World Health Organization), (2021). Coronavirus disease (2019) (Covid-19): situation report, 72. https://apps.who.int/ iris/handle/10665/331685 Erişim=15 Şubat 2021

Worldometers, (2021). https://www.worldometers.info/coronavirus/ Erişim= 15 Mart 2021 